\title{
BOOKPORT - ONLINE KNIŽNICA NA MIERU
}

Mgr. Andrea Lebedová; andrea.lebedova@cvtisr.sk ; (Centrum vedecko-technických informácií SR)

Dištančné vzdelávanie. Homeoffice. Online meeting. Lockdown. Pojmy, ktoré vládnu súčasnému svetu. Knižničný svet nevynímajúc. Centrum vedecko-technických informácií SR (CVTI SR) ako vedecká knižnica musí reflektovat' aj na túto situáciu a prispôsobit' sa dynamicky sa meniacemu prostrediu, situácii a nárokom svojich použivatelov.

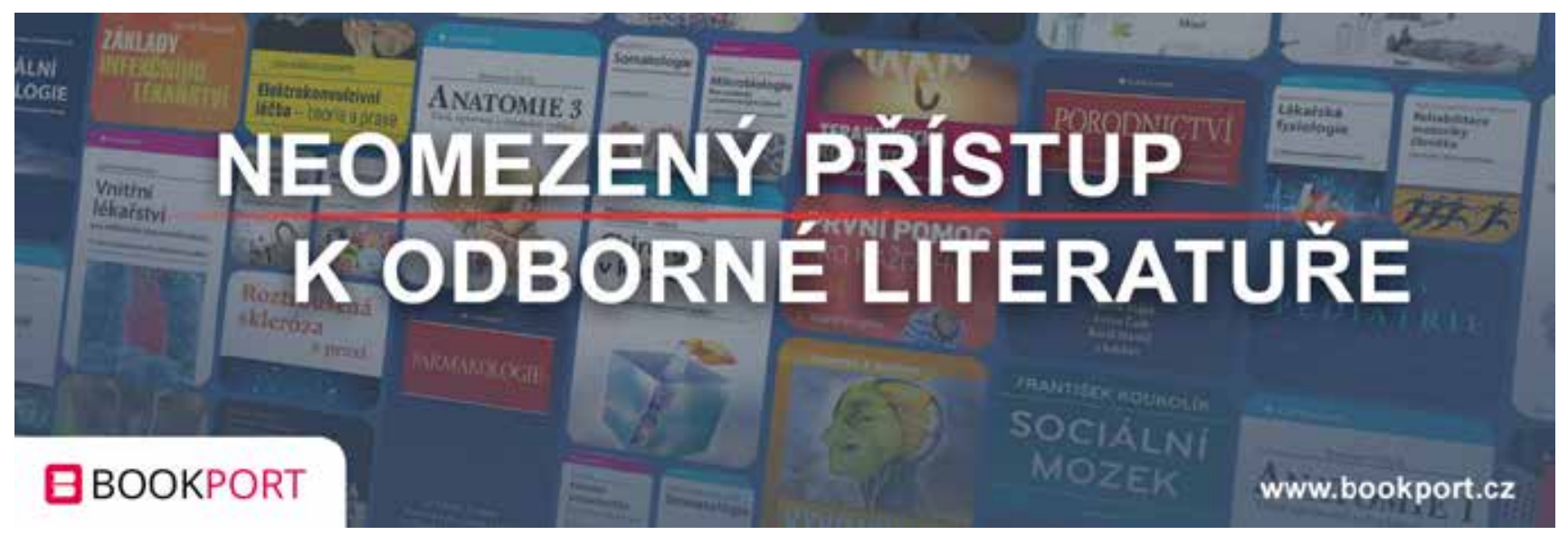

Dištančné vzdelávanie. Homeoffice. Online meeting. Lockdown. Pojmy, ktoré vládnu súčasnému svetu. Knižničný svet nevynímajúc. Centrum vedecko-technických informácií SR (CVTI SR) ako vedecká knižnica musí reflektovat' aj na túto situáciu a prispôsobit' sa dynamicky sa meniacemu prostrediu, situácii a nárokom svojich používatel'ov.

Prostredníctvom vzdialeného prístupu majú používatelia CVTI SR k dispozícii kvalitné, licencované a hodnoverné celosvetové e-zdroje, dostupné 24/7. Narastajúci záujem o medicínske informácie a zdravotnícku literatúru je reakciou odborníkov, aj časti verejnosti, na stále pretrvávajúci pandemický stav.

Popri renomovaných zahraničných vydavatel'stvách sa tak CVTI SR rozhodlo rozšírit svoje portfólio aj o prístup k plným textom e-kníh z českej produkcie prostredníctvom služby BookPort.

Zastrešuje ju vydavatel'stvo Grada Publishing spolu s d'alšími českými vydavatel'stvami. Napríklad Karolinum, JOTA, Nakladatelství Masarykovy univerzity, Portál, a d’alšie.

Používatel' CVTI SR má tak k dispozícii e-knihy z oblas- ti medicíny a zdravotníctva aj v českom jazyku. Popri lekárskych odboroch však vo viac ako 8500 e-knihách nájde informácie aj z psychológie, pedagogiky, stavebníctva, techniky, ekonomiky či spoločenských vied. Okrem odborných e-kníh sú k dispozícii aj e-knihy na vol'ný čas, beletria, detská literatúra, umenie či kuchárske knihy. Pridanou hodnotou tejto služby je možnost' stiahnut' si e-knihu do vlastného zariadenia a čítat' v offline režime. Každý používatel' si tak môže vytvorit' vlastné konto čitatel'a, do ktorého si môže stiahnut' až šest' e-kníh v jednom čase a do troch rôznych vlastných zariadení (mobil, tablet, čítačka).

Takto si môže text v e-knihe zvýrazňovat', písat' poznámky či vložit' záložku. Čítanie offline je možné vd'aka jednoduchej aplikácii BookPort, ktorú si používatel' môže stiahnut' zdarma cez App Store alebo Goole Play. Návod, ako si vytvorit' konto do BookPortu, nájdete na webovej stránke CVTI SR.

Výhodou služby je aj automatická synchronizácia čítania, takže si používatel' môže cestou autobusom čítat' cez mobil a doma pokračovat' tam, kde skončil, napríklad na tablete alebo čítačke. $\mathrm{V}$ rámci svojho konta si používatel' môže vytvárat' vlastné kolekcie, 
do ktorých si na virtuálnu poličku ukladá e-knihy, ktoré si bud' stiahne na offline čítanie alebo ich ponechá ako svoje oblúbené a l'ahko a rýchlo sa k nim dostane.

Vd'aka tejto funkcii má tak každý používatel' svoju vlastnú online knižnicu šitú na mieru stále pri sebe a celkom zdarma. Kolekcia e-kníh v BookPorte je priebežne doplňovaná o novo vydané tituly, čo svedčí o jej vysokej aktuálnosti.

Všetky e-knihy, ktoré si používatel' otvorí na prečítanie sa automaticky pridajú do sekcie Moje kolekcie - Nedávno rozčítané. Pri d'alšom prihlásení sa nie je potrebné už otvorené e-knihy opätovne vyhl'adávat', ostanú uložené na virtuálnej poličke.

Dôležité odkazy:

CVTI SR / https://www.cvtisr.sk/
Registrácia používatel'a

https://www.cvtisr.sk/cvti-sr-vedecka-kniznica/ specializovana-vedecka-kniznica/vzdialeny-pristup-do-e-zdrojov/registracia-na-vzdialeny-pristup-do-e-zdrojov.html?page id=5369

Vzdialený prístup

http://hanproxy.cvtisr.sk/HAN-AtoZ/atoz.html

Návod na príhlásenie sa a používanie služby BookPort https://www.cvtisr.sk/buxus/docs/2021/bookport navod.pdf

BookPort

https://www.bookport.cz/uvod/

\section{K ŽIVOTNÉMU JUBILEU prof. JELY STEINEROVEJ}

Mgr. Mirka Pastierová, PhD.; mirka.pastierova@uniba.sk; (Katedra knižničnej a informačnej vedy, Filozofická fakulta, Univerzita Komenského v Bratislave)

Prof. PhDr. Jela Steinerová, PhD. oslávila tento rok v júli svoje jubileum. Preto by sme jej spolu s kolegami z Katedry knižničnej a informačnej vedy na Filozofickej fakulte Univerzity Komenského v Bratislave, chceli srdečne zablahoželat' a pri tejto príležitosti sa obhliadnut' do minulosti a pripomenút jej prínos, nielen v oblasti teórie informačnej vedy na Slovensku i vo svetovom rámci, ale aj jej dôležitú rolu pri vzdelávaní študentov, budúcich profesionálov a odborníkov v informačnej vede.

https://doi.org/10.52036/1335793X.2021.3-4.65-67

Jej profesionálna dráha sa začala po absolvovaní magisterského štúdia a získaní titulu PhDr. na Katedre knihovníctva a vedeckých informácií Filozofickej fakulty Univerzity Komenského. Následne prišla do kontaktu s praxou na pozíciách knižničného a výskumného pracovníka vo viacerých organizáciách. Potom, ako v roku 1992 získala na Katedre knižničnej a informačnej vedy (d'alej KKIV) titul PhD., tu ostáva pôsobit' ako odborný asistent. $V$ jej kvalifikačnom raste nasleduje docentúra (1997) a nakoniec v roku 2010 získava najvyšší akademický titul profesor.

Rozmanité aktivity prof. Jely Steinerovej zahŕňajú vel'mi vel'a oblastí, preto následne spomenieme vybrané z nich. Jej činnosti sú samozrejme úzko späté s pôsobením na KKIV, kde sa venuje najmä výskumnej, pedagogickej a publikačnej činnosti či koordinácii medzinárodných spoluprác.

Vo výskume pôsobí často vo vedúcej pozícii ako manažérka projektov zameraných na rôzne oblasti informačnej vedy. Medzi vybrané objekty jej výskumných záujmov patria informačné správanie, relevancia, informačná ekológia, informačné prostredie digitálnej vedy a najnovšie etické aspekty digitálnych technológií. Tieto výskumné problémy a celkovo aj teoretické pozície sú ukotvené v širšom sociálno-kognitívnom a používatel'skom rámci informačnej vedy s dôrazom na interaktívne a ekologické prístupy. 
Prof. Jela Steinerová figuruje ako garant a spolugarant študijného programu Knižničné a informačné štúdiá, ktorý tiež pomáha rozvíjat' a priebežne aktualizovat'. Je predsedníčkou komisií pre štátne záverečné skúšky, rigorózne konanie a členkou Odborovej komisie doktorandského štúdia. Jej pedagogická činnost' je aktuálne zameraná na teóriu a metodológiu informačnej vedy, informačné správanie a informačné produkty. Okrem prednášania vedie a podporuje študentov pri písaní kvalifikačných prác. $V$ rokoch 2016 -2020 pôsobila aj vo funkcii vedúcej katedry.

V oblasti publikačnej činnosti prof. Jela Steinerová prispieva tvorbou prác, ktoré pomáhajú posilňovat pozíciu informačnej vedy u nás a v zahraničí. Konkrétne výstupy mapujú už jej spomínané akademické záujmy. Nakol'ko vyprodukovala viac ako 200 publikácií, pokúsime sa vybrat' len niektoré z nich. Monografia "Informačné správanie: pohl'ady informačnej vedy" (Steinerová 2005) spracúva jednu z klúčových oblastí odboru a stala sa dôležitým nástrojom na ukotvenie teoretickej školy v lokálnom prostredí. Táto publikácia zhrnula nielen teoretické aspekty, ale aj praktické problémy interakcie človeka s informačným prostredím. Neskôr prof. Jela Steinerová publikovala vysokoškolskú učebnicu „Informačné stratégie v informačnom prostredí" (Steinerová, Grešková, Ilavská 2010), ktorá sprehl'adňuje fundamentálne kategórie informačnej vedy ako (už vyššie spomínané) informačné správanie, ale aj vyhladávanie informácií a informačný prieskum, informačné stratégie z používatel'ského aj systémového pohl'adu, informačný horizont, organizácia poznania a digitálne knižnice. Okrem detailnej konceptuálnej analýzy učebnica prináša prehl'ad praktických metód a nástrojov vyhladávania a organizácie informácií.

Medzi d'alšie významné publikácie patrí monografia „Informačné prostredie a vedecká komunikácia: Informačné ekológie" (Steinerová 2018). Autorka v nej identifikuje zmeny informačného prostredia vedy, analyzuje modely vedeckej komunikácie a digitálnej vedy a existujúce výskumy. Publikácia prináša výsledky kvalitatívneho výskumu informačného správania vedcov z perspektívy procesov, informačných objektov a špecifických faktorov vplyvu. Na základe výskumných záverov boli sumarizované modely a odporúčania dôležité pre teóriu a relevantné pre prax. Jednou z najaktuálnejších publikácií, ktoré prof. Jela Steinerová editovala, je „Informačná veda: výkladový slovník" (Steinerová, Ondrišová, 2020). Slovník mapuje viac ako 100 najdôležitejších hesiel terminológie informačnej vedy, na ktorých tvorbe sa podie- l'al tím odborníkov z KKIV. Výkladový slovník sa stal užitočnou pomôckou nielen pre študentov odboru, ale aj pre širšiu akademickú komunitu. $V$ širšom pohlade tento slovník významnou mierou prispieva $\mathrm{k}$ organizácii poznania a vymedzeniu konceptuálnych základov informačnej vedy. Okrem monografií, vysokoškolských učebníc a skrípt publikovala prof. Jela Steinerová aj výskumné správy k realizovaným projektom (Steinerová et al. 2004, Steinerová, Grešková, Šušol 2007, Steinerová et. al 2012), štúdie, vedecké články a príspevky k prezentáciám na množstve domácich a zahraničných konferencií. Kompletný prehl'ad jej prác je dostupný pomocou databázy publikačnej činnosti Akademickej knižnice UK (Evidencia 2021).

Prof. Jela Steinerová absolvovala zahraničné pobyty v USA, UK, Belgicku a Pol'sku. Aktuálne koordinuje medzinárodné spolupráce KKIV so zahraničím a participuje aj na projektoch s globálnym dosahom. Pôsobí v redakčných radách odborných časopisov na Slovensku a v zahraničí, ako napr. Information Research, Mousaion, ProlnFlow. Od roku 2008 je predsedníčkou redakčnej rady zborníka Knižničná a informačná veda. Je členkou programových výborov konferencií a množstvo z nich aj organizuje. Aktuálne zastrešuje konferenciu „Informačné interakcie”, ktorá poskytuje priestor na prezentáciu výskumných projektov KKIV, ale aj príspevkov d'alších odborníkov zo Slovenska a zahraničia.

Môžeme zhrnút', že prof. Jela Steinerová, PhD. patrí aktuálne medzi špičku v oblasti informačnej vedy na Slovensku a kontinuálne prezentuje odbor aj katedru v zahraničí. Pomáha budovat́ odbor a upevňuje miesto informačnej vedy prostredníctvom jej rozsiahlej výskumnej, publikačnej a prednáškovej činnosti. Je zakladatel'kou významnej vedeckej školy zameranej na informačné správanie, ktorú prezentuje aj ako pozvaná expertka v zahraničí. Nadväzuje nové spolupráce, podporuje študentov pri odbornom raste a pomáha aj kolegom na katedre, za čo jej patrí vel'ká vd'aka.

Drahá Jela, pri príležitosti Tvojho jubilea mi v mene celej Katedry KIV dovol' popriat' Ti z celého srdca najmä vel'a zdravia a spokojnosti. Nech sa splnia všetky tvoje želania a sny.

$V$ mene kolektívu Katedry knižničnej a informačnej vedy, FiF UK v Bratislave 


\section{Zdroje}

Evidencia publikačnej činnosti [online], C2015. Bratislava: Akademická knižnica UK. [cit. 2021-07-14]. Dostupné na: https://alis. uniba.sk:8444/search/query?match_1=PHRASE\&field_1=a\&term_1=Steinerová,+Jela+1961-+UKOFIKN\&theme=EPC

STEINEROVÁ, J. et al, 2004. Správa o empirickom prieskume používatel'ov knižníc ako súčast' grantovej úlohy VEGA 1/9236/02 Interakcia človeka $s$ informačným prostredím $v$ informačnej spoločnosti. Bratislava: Filozofická fakulta UK, KKIV, 2004. $113 \mathrm{~s}$.

STEINEROVÁ, J., 2005. Informačné správanie: pohl'ady informačnej vedy. Bratislava: Centrum VTI SR, 2005. 189 s. ISBN 80-85165-90-2. STEINEROVÁ, J., GREŠKOVÁ, M., a J. ŠUŠOL, 2007. Prieskum relevancie informácií: výsledky analýz rozhovorov s doktorandmi FiFUK. Bratislava : CVTI SR, 2007. 150 s. ISBN 978-80-85165-93-7.
STEINEROVÁ, J., GREŠKOVÁ, M., A J. ILAVSKÁ, 2010. Informačné stratégie v elektronickom prostredí. Bratislava: Univerzita Komenského, 2010. 192 s. ISBN 978-80-223-2848-7.

STEINEROVÁ, J. et al, 2012. Informačná ekológia akademického informačného prostredia. Bratislava: Univerzita Komenského, 2012. 96 s. ISBN 978-80-223-3178-4.

STEINEROVÁ, J., 2018. Informačné prostredie a vedecká komunikácia: Informačné ekológie. Bratislava: Univerzita Komenského, 2018. 229 s. ISBN 978-80-223-4445-6.

STEINEROVÁ, J. a ONDRIŠOVÁ, M., 2020. Informačná veda. Výkladový slovník. Autori: Jela Steinerová, Jaroslav Šušol, Pavol Rankov, Lucia Lichnerová, Ĺudmila Hrdináková, Miriam Ondrišová, Marta Špániová, Katarína Buzová, Andrea Hrčková. Bratislava: Univerzita Komenského, 2020. 278 s. ISBN 978-80-223-4866-9. 